\title{
THE LAST WORD HYSTERIA IN THE HALLS OF CONGRESS
}

\author{
by Geoffrey M. Karny
}

T

he latest forum for the long-running debate on the social impacts of biotechnology is a series of hearings by the House Judiciary Committee's subcommittee on courts, civil liberties, and the administration of justice. These meetings were sparked by a recent U.S. Patent Office decision to permit patents on animals. The anti-patent position became clear at the initial hearing on June 11, 1987, when two witnesses treated Congress and the public to a gloom-and-doom scenario on the consequences of patenting living organisms. Such a hearing normally should not be viewed as particularly threatening to the biotechnology industry. However, it represents the start of an orchestrated campaign to overturn recent Supreme Court and Patent Office decisions that recognize the legality of patenting nonhuman, living organisms.

The anti-patent position has been traditionally countered in two ways: by showing how the patenting of living organisms is clearly consistent with the patent statute, congressional and constitutional policies, and Supreme Court decisions; and by pointing to the documented connection between patents and innovation.

But there are even more fundamental objections to the anti-patent position. Quite simply, it is misleading, manipulative, and hostile to business and property rights.

The anti-patent witnesses at the first hearing were Jack Doyle, director of the Agriculture Resources Project of the Environmental Policy Institute, and John A. Hoyt, president of the Humane Society of the United States.

Mr. Doyle's thesis is that patents will allow a few large corporations to control agriculture and to exercise unreasonable power. He stated, "It seems that many of the advantages for a patent system flow to help a few people get rich quick, while passing along higher costs to farmers and consumers." Patents, according to Mr. Doyle, are the linchpin of intense corporate activity in agricultureparticularly acquisitions of companies, with the "superconglomerates" supposedly leading the way.

$\mathrm{Mr}$. Hoyt raised the so-called animal rights and moral issues. For him, patenting animals "violates the basic ethical precepts of civilized society and unleashes the potential for uncontrollable and unjustified animal suffering." Portraying a gloom-and-doom scenario supported only by hyperbolic speculation and inflammatory language, he asserted that "there will surely be a dramatic increase in the suffering of animals," that such suffering "will be cloaked in secrecy," and that patenting will "cloud the ownership of wild animals." Mr. Hoyt really hit his stride on the so-called ethical issues. The subcommittee heard rhetoric such as "a human arrogance toward other living creatures that is contrary to the concept of the inherent sanctity of every unique being" and "a dominionistic and materialistic attitude toward living beings." With a final leap into the abyss of hyperbole, he asserted that the result of patenting living organisms "would be to potentially enslave all species, including our own."

The most charitable thing that can be said about these arguments is that they show a fundamental misunderstanding of inventions, patents, and economic activity.
More troubling, however, is their manipulative, hysterical tone and the undercurrent of hostility to property rights and ordinary corporate activity.

Doyle and Hoyt ignore the basic fact that our society has always recognized property rights in animals, whether they are house pets or livestock. In this sense, patenting animals is nothing new.

The critics also overlook the simple fact that, but for the creativity and hard work of the inventor, the new living organism would not exist. Thus, the inventor takes nothing from the public, but instead gives something to it. And when the invention is patented, the inventor turns over the knowledge embodied in it and, after 17 years, the rights to the invention itself. If he were to keep it a secret, which is perfectly legal, then the public would gain only the product.

Doyle and Hoyt also apparently do not understand that a patent is simply a property right, not a guarantee of commercial success. Most inventions do not reach the marketplace. When they do, the price that can be charged will be limited by the dynamics of the marketplace itself. If a patented seed or animal is being sold at an unacceptably high price, farmers will simply substitute another product.

Moreover, attempting to blame patents for the increasing concentration in the agriculture industry is a red herring. Concentration is increasing in many sectors of the economy, including those where patents play only a minor role. If such concentration is improper, it can be addressed by the antitrust laws. If Mr. Doyle believes these laws are inadequate, he should attempt to convince Congress to amend them rather than the patent law.

In reading Mr. Doyle's description of business activity in biotechnology and agriculture, one must ask the question: "So what?" Aren't those who take the risks and put in the hard work entitled to rewards? Why is this activity being criticized? The only reason that comes to mind is that the critics have a basic hostility toward property rights and free enterprise. There appears to be an implicit assumption that the fruits of a person's or company's efforts must suddenly be available to everyone who wants them with no regard to the owner's basic right to prohibit others from using them or to charge them for that right.

Finally, and most troublesome, is the entire approach and rhetoric of the anti-patenting people. Mr. Doyle's analysis appears to rely on the implicit stereotype of corporations as conspiratorial evil-doers. Mr. Hoyt's rhetoric appears to be calculated to inflame emotions rather than deal with facts and logical analysis. Their end-of-theworld scenarios may be appropriate for their own fund raising activities, but certainly have no place in the halls of Congress.

Geoffrey M. Karny is a principal specializing in the patenting and regulation of biotechnology at the law firm of Dickstein, Shapiro \& Morin, 8300 Boone Boulevard, Suite 800, P.O. Box 2537, Vienna, VA 22180. These opinions are the author's own and are not necessarily those of Bio/Technology, the law firm, or any of its clients. ${ }^{-}$Geoffrey M. Karny, 1987. 